\title{
Analysis of the Selection of Alternative Work Methods for Structural Work Using the Zero-One Method at the Guest Room Building Development Project in Sanur, Bali
}

\author{
Ni Ketut Evi Kusumadewi ${ }^{1}$ \\ Civil Engineering Department \\ Bali State Polytechnic \\ Bali, Indonesia \\ ${ }^{1}$ kusumaevi960@gmail.com
}

\author{
I Wayan Sudiasa ${ }^{2}$ \\ Civil Engineering Department \\ Bali State Polytechnic \\ Bali, Indonesia \\ ${ }^{2}$ sudiasawayan@yahoo.com
}

\author{
Made Sudiarsa ${ }^{3}$ \\ Civil Engineering Department \\ Bali State Polytechnic \\ Bali, Indonesia \\ ${ }^{3}$ madesudiarsa42@yahoo.com
}

\begin{abstract}
There were various alternative construction work methods that could be chosen as the most suitable in order to achieve the project's final goal by using the resources efficiently with an optimum result (cost, quality, and time). The alternative work methods could be applied on various projects, such as building project which had medium-large scale to small scale. The construction of Guest Room Building development project located in Sanur, Bali, had a large and complex structural work that needed alternative work method which was considered as the most suitable method. Both alternatives had differences in cost and implementation time. The spending cost of Alternative I method obtained Rp 1,620,731,471 in 57 days of duration. On the other hand, the spending cost of Alternative II method obtained Rp 1,592,353,471 in 49 days of duration. The saving cost obtained was $R p 2,837,800,000.00$ or $1.75 \%$ with 8 days difference of duration. Based on the zero-one analysis method used, alternative II became the most suitable methods which assessed by using some parameters (cost saving, quality, time, the convenience of implementation, and environmental impact).
\end{abstract}

Keywords-work method; best alternative; zero-one introduction

\section{INTRODUCTION}

The development of the construction industry is closely linked with the implementation of the development in all fields is still being vigorously implemented. Construction activities consist of various phases, where the most decisive stage is the planning and implementation of construction projects the overall quality is very dependent on the
Creation and management at that stage. Every construction project has limits and goals that are generally referred to the triple constraint which are quality, time and cost. It is demanding any construction project can reach the limits and objectives.

Incompatibility with expectation realization on construction projects could potentially cause harm to the owner, contractor, or both. Many cases of construction projects, particularly the construction of the building in which the implementation is not in accordance with the planning, such as cost overruns (cost overrun), timing of late, and the quality of work is not in accordance with the technical specifications that led to the reemployment (rework). It is caused by several factors such as human error, the number of less labor, design changes, limited materials and tools, working methods improper construction and others. This problem can be anticipated by applying good management and proper, because success depends on the management of construction projects are implemented, both field management and resource management.

In managing the Project Management (Project Management), there are three main factors that must be taken into consideration, the time according to plan, a realistic cost and within budget and the quality that can be accounted for. These three factors are often cited as obstacles in the implementation of the construction project called Triple Construction. The third performance of these factors also influenced by the use of resources in the project, which is better known as the five management vehicle construction purposes $(5 \mathrm{M})$ is the cost (money), labor (man power), material, working methods, and machine. 
In the process of achieving the goals of a construction project, there are limits that must be met, namely the cost (budget) is allocated, schedule and quality that must be met. One of the elements of construction management which affect the achievement of project goals or objectives are the working method (method) is used. The use of less precise methods of work will have an impact on the delay time of completion of the work, or swelling costs or both that the delay time of completion of the work and the swelling cost of construction. Instead the selection of appropriate working methods will result in the construction process efficiency gains in the form of financial benefits and the potential to shorten the duration of construction and reduce operational time various related equipment. Efficient and optimal results (right cost, quality and time).

The applicability of alternative working methods can be applied in various projects, such as building projects that have small, medium to large scale. One of the projects that can be done the application of the use of alternate work method is Guest Room Building developmnet project located in Sanur, Bali. The project is currently working on the job structure, consisting of a bottom structure (foundation and sloop) and upper structure (slabs, beams, and columns).

To complete the structural work, the project is applying the methods of work such as in the provision of scaffolding, use of human resources and the use of heavy equipment to facilitate the work of casting. Thus this project has the opportunity to seek the best alternatives that the optimal region contributes to the work.

\section{RELATED RESEARCH}

\section{A. Project Management}

The construction project is a series of activities that are only carried out once and are generally short-term. In this series of activities, there is a process that processes project resources into a result of activities in the form of buildings [1]. Construction management is how the resources involved in construction projects can be applied appropriately by the project manager. Resources in construction projects can be classified into labor (manpower), material (material), tools (machines), costs (money), and working methods (method) [2].

\section{B. Work Method}

The work method is essentially the elaboration of the procedures and techniques for carrying out the work, which is the core of all activities in the construction management system [3]. Work methods are the key to be able to realize all planning into physical forms. Basically the work method is the application of the engineering concept based on the relationship between the requirements in the tender document (procurement documents), the technical and economic conditions in the field, and all resources including the contractor's experience. The combination and interrelation of the three elements interactively form the framework of ideas and concepts of the optimal method applied in the construction implementation. The concept of the implementation method includes the selection and determination related to the overall aspects of the work, including temporary facilities and infrastructure requirements [4].

\section{Time Cost of Trade}

In the time cost analysis of this trade off with the change in the completion time of the project, the costs that will be incurred also change. If the execution time is accelerated, the direct costs of the project will increase and the indirect costs of the project will be reduced.

\section{Work Productivity}

Productivity is the ratio of the total output in the form of goods and services at a certain time divided by the total inputs which can include: man-power, management, material, capital, and machines owned. Based on some of the definitions above, it is clear that easily, this productivity can be interpreted as output divided by input. However, from this understanding a problem arises that although it is quite easy to define the inputs needed to carry out a production activity in quantitative units which will later be easily analyzed further (usually expressed in units of Rupiah, People-Days, etc.) [5].

\section{E. Structure}

The definition of structure in the context of its relationship with the building is as a means to channel the burden and due to its use and or the presence of buildings into the ground. Broadly speaking, the structure of the building is divided into 2 equal parts, the building structure on land is often called the upper structure, while the building structure that is in the ground, is often called the bottom structure (sub structure) [6].

\section{F. Formwork}

Formwork is a temporary structure with the aim to support and protect fresh concrete until it can support itself. So that the shape, size of the concrete, position and location of the building are as desired [7].

\section{G. Zero-One}

Zero-one method is a method of decision making that aims to determine the priority order of functions (criteria). The principle of this method is to determine the relativity of a function "more important" or "less important" to other functions. The "more important" function is given a value of one (one), while the "less important" value is given a zero (zero) then by presenting a comparison reference, finally an index is obtained for each criterion that will later become the calculation parameter in determining the decision making value for each alternative based on the predetermined criteria. The advantage of this method is easy to understand and the implementation is fast and easy [8].

\section{RESEARCh METHODOLOGY}

This research was conducted on a private project that was working on the structure work, using descriptive research method. Descriptive qualitative data analysis method in this research is useful for developing a theory that has been built from the data that have been obtained in the field. Qualitative research methods at the initial stage researchers conducting 
exploration, then data collection to deep, from observation to analysis data..

\section{A. Data Source}

Data needed in this research consisted of primary data and secondary data. Primary data was obtained through direct surveys and field obverse. Which included primary data in this study are: election factor working methods, ranking functions, labor productivity, productivity tools, and the unit price of equipment, materials and wages of workers Secondary data is data that is obtained in the form of ready-made and has provided relating to the construction of the Guest Room Building developmnet project. This data was obtained directly from the constructor implementers. Which included secondary data in this study are a shop drawing, time schedule and BQ.

\section{B. Determined Alternatives}

The four alternatives are analyzed, namely one exiting and 3 other alternatives. (1) Existing alternatives consist of: scaffolding work done by renting scaffolding, formwork columns using tego film plywood and assisted with scaffolding as support, transport of material to the work floor is assisted by a tower crane. The concrete used is Ready-mix K-350, the job of casting slab and beam using a combination of advance of the CP (concrete pump) with TC (tower crane), while for casting columns using TC, (2) alternate two consists of: the work scaffolding is done by hire scaffolding, formwork columns using tego film plywood and assisted with scaffolding as support, transport of material to the work floor is assisted by a tower crane., the concrete used is Ready-mix K350, foundry work, slab and beam using a concrete pump., working hours are applied is 9 hours, the number of artisans each job plus one of the number of artisans in the existing, (3) alternate three consisted of: work scaffolding is done by renting scaffolding., formwork columns using plywood usual and assisted with steel pipes as support, transportation of materials to the aided by the work floor tower crane, concrete used there was Ready-mix $\mathrm{K} 350$, foundry work, slab and beam using the elevator cast, while for casting columns using TC, working hours are applied is 8 hours, (4), while the alternative of four using a conventional system comprising: scaffolding and formwork plates and beams done with conventional systems as well as using wood dolken as support, formwork columns using plywood usual and assisted with wood dolken as support, transportation of materials to the floor of the work done by hand, the concrete used is concrete made with system site mix, foundry work done by lift cast, working hours are applied is 9 hours, and the number of workers plus $15 \%$ of the existing. The research instrument used consisted of (1) a questionnaire to rank or ranking factors working method selection, and (2) the stopwatch to calculate productivity in the field.

\section{Research Stage}

1. Information

At this information stage efforts are made to get as much information as possible that is relevant to the object of the study to be evaluated, where the data and information are processed according to needs in the next stage. General information needed includes: project name, project location, project scope, and project implementation time.

2. Analysis

The analysis phase aims to hold an analysis of each alternative in accordance with the five dominant factors that are taken into consideration in choosing the method of work in the Guest Room Building developmnet project, Sanur Bali.

1. Analyze the ranking of functions

2. Conduct a preference analysis of the five selected functions.

3. Choose the best alternative from the results of the analysis. The selection of alternatives is done by the zero-one method.

3. Recommendation

Recommendation stages provide recommendations that can be in the form of a written or oral presentation of the best alternative that has been chosen, to be shown to all parties, including owners, planners and implementers. In the recommendation stage, it can also contain the best alternative proposals that are emancipated and the reasons for choosing why these alternatives are based.

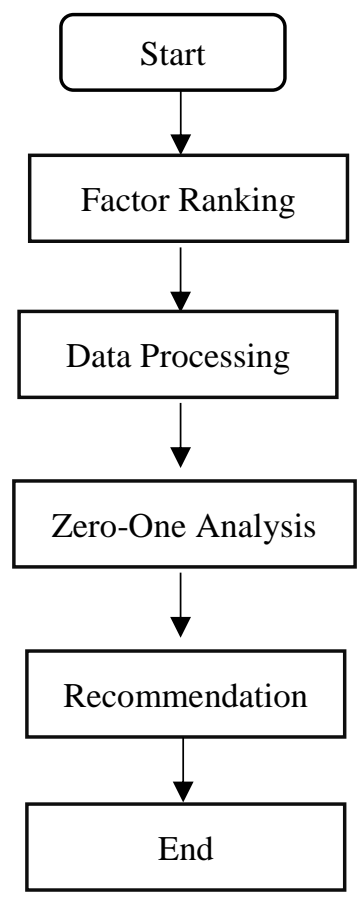

Fig. 1. Research Stages

\section{EXPERIMENT RESULT}

The results of the questionnaire obtained by the selection of the factors and their working methods percentage. Based on Table 4.2 The highest priority is the cost factor $(21 \%)$, the second highest priority is quality (18\%), then the third-highest priority is the time $(17 \%)$, then the next priority of ease of 
implementation (10\%), environmental impact (9\%), K3 (8\%), mobilization tool (5\%) availability of tools (5\%), field conditions (4\%), and the lowest priority is the availability of labor $(3 \%)$. From the results of the analysis phase of the cost and time of execution of each alternative cost the comparison are the direct costs consist of the cost of materials, wages and tools. Most cost-effective alternative selected as the best alternative from the cost saving function. Here is a comparison of the direct costs of each alternative.

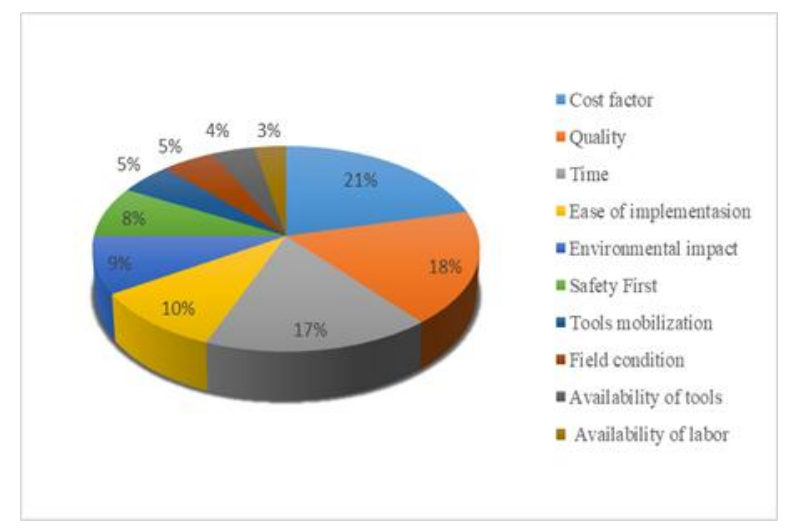

Fig. 2. Rank of Factor

Cost - The cost and time of execution of each alternative cost the comparison are the direct costs consist of the cost of materials, wages and tools. Most cost-effective alternative selected as the best alternative from the cost saving function. Here is a comparison of the direct costs of each alternative.

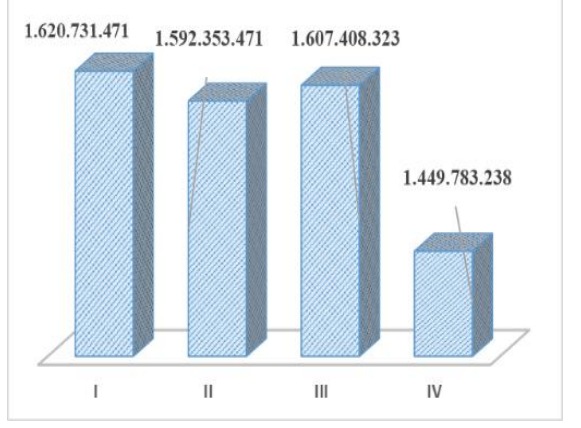

Fig. 3. Cost Analysis Result

Based on the cost comparison graphs, it can be concluded that the alternative that produces the most direct cost saving is an alternative IV, Rp. 1.449.783.238 with a savings of $(10.55 \%)$, while the next most cost-effective is the second alternative, Rp. 1.592.353.471 with a savings of (1.75\%) and direct costs are worth being alternatives III, Rp.1.607.408.323 with a savings of $(0.82 \%)$ and most direct costs generated by using alternative I Rp.1.620.731.471.

Quality- Quality compared in this study is the quality of concrete with Ready-mix and site-mix system. Ready-mix concrete quality is better than site-mix in terms of quality assurance. Process Ready-mix made with a mortar-making in batching plan with mortar consistency levels are maintained. In this case it can be concluded that the alternative use Ready-mix concrete is better than alternatives using concrete site-mix.

Time-In this study the alternative that produces the fastest implementation time, was chosen as the best alternative. The resulting execution time comparison of each alternative can be seen on the graph.

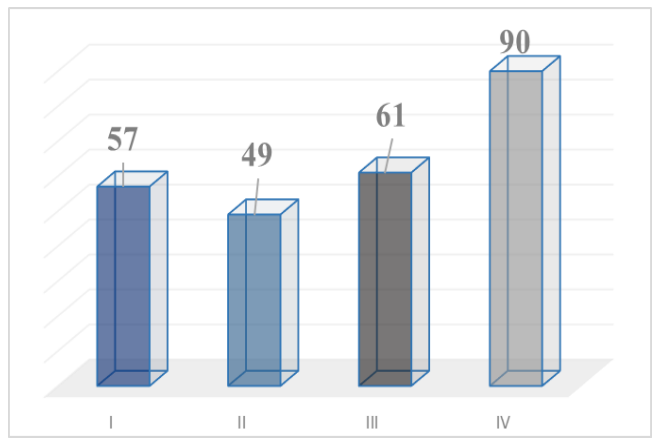

Fig. 4. Time Analysis Result

According to the graph above, the alternative that produces the shortest duration is using alternatives II (49 days), then the shortest duration of the following is an alternative I (57 days), then the duration of the third (61 days), and the longest duration is generated by using alternative IV ( 64 days). It can be concluded that by increasing the hours of work and the number of artisans can produce a shorter (Alternative II).

Ease of Implementation - Ease of implementation judged by the amount of time required to complete the execution of each job. Alternatives that generate the shortest duration is judged to have the level of the most excellent ease of implementation, so that the alternative that has the best convenience is to use the second alternative, while alternative that has the ease of implementation is not good is using an alternative IV.

Environmental Impact- The environmental impact assessment criteria in this study are the amounts of waste arising from the use of working methods are used. Item jobs likely to bring the waste are the work scaffolding, formwork and casting. In this case it can be concluded that the alternative use of conventional systems is considered to have potential impacts. The highest environment, while alternative I, III and III are considered to have the potential for lower environmental impact. Prior to the assessment process, the need to develop or assign weights to each criterion owned. The sequence in doing sorted rate based on the results of the analysis of questionnaires.

The method of implementing this zero-one method is to collect functions of the same level, then arranged in a square zero-one matrix. Then an assessment of functions in pairs is carried out, so there is a matrix that will fill $\mathrm{x}$. The values in this matrix are then summed according to lines and collected in the sum column.

TABLE I. ZERO-ONE FINAL RESULT

\begin{tabular}{|c|c|c|c|c|c|c|c|}
\hline \multirow{2}{*}{ No } & \multirow{2}{*}{ Alternative } & \multicolumn{5}{|c|}{ Function } & \multirow{2}{*}{$\begin{array}{c}\text { Percentage } \\
(\%)\end{array}$} \\
\hline & & $\mathbf{A}$ & B & C & D & $\mathbf{E}$ & \\
\hline \multirow{3}{*}{1} & \multirow{3}{*}{ I } & 33.3 & 26.7 & 20 & 13.3 & 6.7 & \multirow{3}{*}{22} \\
\hline & & $0 / 6$ & $2 / 6$ & $2 / 6$ & $2 / 6$ & $2 / 6$ & \\
\hline & & 0 & 8.9 & 6.7 & 4.4 & 2.2 & \\
\hline \multirow{2}{*}{2} & \multirow{2}{*}{ II } & $2 / 6$ & $2 / 6$ & $3 / 6$ & $3 / 6$ & $2 / 6$ & \multirow{2}{*}{39} \\
\hline & & 11.1 & 8.9 & 10 & 6.7 & 2.2 & \\
\hline \multirow{2}{*}{3} & \multirow{2}{*}{ III } & $1 / 6$ & $2 / 6$ & $1 / 6$ & $1 / 6$ & $2 / 6$ & \multirow{2}{*}{28} \\
\hline & & 11.1 & 8.9 & 3.3 & 2.22 & 2.23 & \\
\hline \multirow[b]{2}{*}{4} & \multirow{2}{*}{ IV } & $3 / 6$ & $0 / 6$ & $0 / 6$ & $0 / 6$ & $0 / 6$ & \multirow[b]{2}{*}{17} \\
\hline & & 17 & 0 & 0 & 0 & 0 & \\
\hline
\end{tabular}


The results of analysis that the second alternative is the best alternative that has the highest total weight advantage of $39 \%$. The weight value is obtained based on the following criteria (A) $11.1 \%$ cost savings, (B) the quality of $8.9 \%$ (C) the timing of the $10 \%$, (D) $6.7 \%$ ease of implementation, and (E) the environmental impact $2.2 \%$.

At the stage of recommendation give recommendations on the best alternative to do the work of the structure. From the analysis that has been done before using zero one, recommended best alternative is to use alternative II. This stage is the final stage in the analysis which aims to provide recommendations regarding the best alternative to do structural work. From the analysis that has been done previously using the zero-one method, the best alternative is recommended using alternative II on the basis of the following considerations (1) save on implementation costs of Rp. 28,378,000 from the existing with a cost savings of $1.75 \%$ (2) quality of concrete is guaranteed and quality (3) efficient in the execution time of 8 (eight) days from the existing work is easier (5) does not cause a lot of waste in the field.

\section{CONCLUSION}

Based on the analysis of dominant factor in the selection of working methods and the selection of the best alternative to structure work on the construction project Guest Room Sanur, Bali, be concluded that (1) The dominant factor into consideration in selecting the method of working is cost savings, quality, time, ease of implementation, and environmental impact, (2) of 4 (four) alternatives analyzed, alternative II is the best alternative to the weighting matrix zero-one of $39 \%$ as assessed factor of cost savings, quality, time of implementation, ease of implementation, and impact environmental advice

\section{ACKNOWLEDGMENT}

The authors would like to express the great thank to Directorate General for Research strengthening and Development, Ministry of Research, Technology and Higher

Education, Republic of Indonesia as the sponsor of this research through the scheme of prime university research grants.

\section{REFERENCES}

[1] W.I. Ervianto, Manajemen Proyek Konstruksi, Edisi Revisi, Penerbit Andi, Yogyakarta, 2018.

[2] A. Wibowo, "Survei Persepsi Pengajuan Klaim Atas Keterlambatan Akibat Pihak Pemilik Pada Proyek Konstruksi Pemerintah," Prosiding, [Konfrensi Nasional teknik Mesin 3, 2009].

[3] W.I. Ervianto, Teori -Aplikasi Manajemen Proyek Konstruksi. Yogyakarta Penerbit ANDIErvianto, W.I., Manajemen Proyek Konstruksi, Yogyakarta: Penerbit Andi, 2005.

[4] I. Dipohusodo, Manajemen Proyek dan Konstruksi.Jilid 1 \& 2 Yogyakarta. Penerbit Kanisius, 1996.

[5] H.R. Thomas, "Labor Productivity and Work Sampling: The Bottom Line," J. Construc. Eng. and Manag., vol. 117, no. 3, 1991. 